PERM JOURNAL OF PETROLEUM AND MINING ENGINEERING

ВЕСТНИК ПНИПУ. ГЕОЛОГИЯ. НЕФТЕГАЗОВОЕ И ГОРНОЕ ДЕЈО

ISSN 2224-9923

Volume / Tом 16 №4 2017

http://vestnik pstu.ru/geo/

УДК 551.1:553.98

Article / Статья

(C) PNRPU / ПНИПУ, 2017

\title{
FEATURES OF GEOLOGICAL STRUCTURE AND FORMATION OF OIL \& GAS DEPOSITS IN THE VUKTYL THRUST FAULT REGION
}

\section{Elena A. Kuznetsova, Tatyana V. Karaseva}

Perm State National Research University (15 Bukireva st., Perm, Russian Federation, 614068)

\section{ОСОБЕННОСТИ ГЕОЛОГИЧЕСКОГО СТРОЕНИЯ И ФОРМИРОВАНИЯ НЕФТЕГАЗОНОСНОСТИ В РАЙОНЕ ВУКТЫЛЬСКОГО НАДВИГА}

\section{Е.А. Кузнецова, Т.В. Карасева}

Пермский государственный национальный исследовательский университет (614068, Россия, г. Пермь, ул. Букирева, 15)

Received / Получена: 01.09.2017. Accepted / Принята: 06.10.2017. Published / Опубликована: 01.12.2017

Key words:

field, Vuktyl thrust, autochthon, reservoir, well, basin modeling, software, PetroMod, oil and gas deposits, organic matter, hydrocarbons, catagenesis, generation, deeply buried sediments, section.

\section{Ключевые слова:} месторождение, Вуктыльский надвиг, автохтон, залежь, скважина, бассейновое моделирование, программа, PetroMod, нефтегазоносность, органическое вещество, углеводороды, катагенез, генерация, глубокопогруженные отложения, разрез.

\begin{abstract}
The paper is devoted to modeling of the processes of oil and gas deposits formation of the Vuktyl thrust development area, to which the largest in the Timan-Pechora oil and gas province is associated with the same oil and gas condensate deposit. Oil and gas of deeply buried formations of the autochthon of the overthrust region remains poorly studied. Therefore, application of modern methods of basin modeling is relevant for oil and gas content estimation. In order to simulate the section, Schlumberger PetroMod software package was used. The package allows to determine the history of generation of hydrocarbons on the geological time scale, migration paths, amount and type of oil and gas accumulations in both surface and reservoir conditions. Using the 1D and 2D modeling of the Vuktylskaya-58 parametric well and the overthrust region models were obtained. The models reflect the modern geological section, its evolution during the geological time. The processes of formation of oil and gas were studied. As a result, it was shown that the parent rocks of the allochthonous section part could not participate in the formation of the main gas-condensate deposit of the Vuktyl deposit because they entered only the main oil formation zone. In deeply buried deposits of the autochthon starting from the Permian and Triassic formation of the Vuktylsky gas-condensate field and possibly the deposits in poorly studied deep formations could be caused by processes of generation of gases and gas condensates. That is proved by the discovery of a large number of gas emergences beyond the $4-5 \mathrm{~km}$ in a section of the only well drilled beyond the $6 \mathrm{~km}$ such as Vuktylskaya-58. Generation and accumulation of gas hydrocarbons occurred mainly after the appearance of thrust dislocations, when the main traps were formed both at ordinary and high depths.
\end{abstract}

Статья посвящена моделированию процессов формирования нефтегазоносности района развития Вуктыльского надвига, к которому приурочено крупнейшее в Тимано-Печорской нефтегазоносной провинции одноименное нефтегазоконденсатное месторождение. Нефтегазоносность глубокопогруженных отложений автохтона района надвига остается малоизученной, поэтому для ее оценки актуально использование современных методов бассейнового моделирования. Для моделирования разреза был использован программный комплекс РеtroMod компании Schlumberger, который позволяет определить историю генерации углеводородов в масштабе геологического времени, пути миграции, число и тип накоплений нефти и газа как в поверхностных, так и в пластовых условиях. С помощью $1 \mathrm{D}-$ и 2D-моделирования разрезов параметрической скважины Вуктыльская-58 и района надвига были получены модели, отражающие современный геологический разрез, его эволюцию в течение геологического времени, а также изучены процессы формирования нефтегазоносности. В итоге показано, что материнские породы аллохтонной части разреза не могли участвовать в формировании основной газоконденсатной залежи Вуктыльского месторождения, так как вступали только в главную зону нефтеобразования. В глубокопогруженных отложениях автохтона начиная с пермско-триасового времени происходили процессы генерации газов и газоконденсатов, которые могли обеспечить формирование залежи Вуктыльского газоконденсатного месторождения, а также, вероятно, и залежей в малоизученных глубоких горизонтах, что подтверждается обнаружением большого числа газопроявлений ниже 4-5 км в разрезе единственной скважины, пробуренной ниже 6 км - Вуктыльской-58. Генерация и аккумуляция газообразных углеводородов происходили в основном после проявления надвиговых дислокаций, когда были сформированы основные ловушки как на обычных, так и на больших глубинах.

Elena A. Kuznetsova (Author ID in Scopus: 56711646200) - Senior Lecturer at the Department of Regional and Oil\&Gas Geology (mob. tel.: +007 91248 79 384, e-mail: e.lena.kuznetsova@yandex.ru). The contact person for correspondence.

Tatyana V. Karaseva (Author ID in Scopus: 37111172100) - Doctor of Geology and Mineralogy, Professor, Honored Geologist of Russia, Head of the Department of Regional and Oil\&Gas Geology (mob. tel.: +007 9124879 384, e-mail: regional.PSU@yandex.ru).

Кузнецова Елена Александровна - старший преподаватель кафедры региональной и нефтегазовой геологии (моб. тел.: +007 9124879384 , е-таil: e.lena.kuznetsova@yandex.ru). Контактное лицо для переписки.

Карасева Татьяна Владимировна - доктор геолого-минералогических наук, профессор, заслуженный геолог России, заведующая кафедрой региональной и нефтегазовой геологии (моб. тел.: +007 9124879 384, e-mail: regional.PSU@yandex.ru). 


\section{Introduction}

Vuktylskoe oil and gas condensate field is the largest in Timan-Pechora province and was discovered in 1964. Since that moment, the geological structure has been studied and specified. The field is located in the northern part of the Upper Pechora depression of the Predural edge trough and is confined to the complex swell-like asymmetric fold of a submeridional strike of more than $80 \mathrm{~km}$ in length, at least $4 \mathrm{~km}$ wide and vertical amplitude of $1500-1800 \mathrm{~m}$. The structure has a gently sloping eastern and steep western wings, disturbed by an oblique-slip fault with $1 \mathrm{~km}$ vertical and $2.8 \mathrm{~km}$ horizontal amplitude (Fig. 1). Paraautochthonous blocks of the cross-section are distinguished with different confidence level. Commercial oil and gas are revealed in the allochthonous part of the section. A unique gas-condensate fied is found predominantly in carbonate Carboniferous-Lower Permian deposits. The main field is considered to be massive, tectonically shielded and has a single gaswater contact [1].

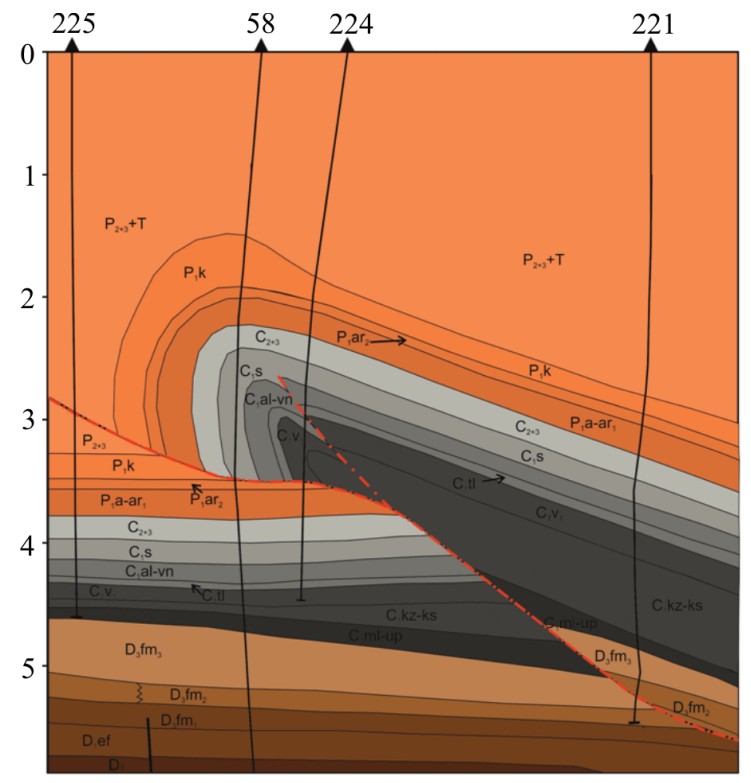

Fig. 1. Schematic geological section of the Vuktyl thrust along the line of wells 225-58-224-221 [3]

Allochthon deposits of the Vuktyl overthrust are located at the final stage of development [2]. At the same time oil and gas content of the deep burried deposits of the autochthon remains poorly studied. So, it is important to use the newest methods of basin modeling to estimate the oil and gas content below the depths studied.

\section{Research method}

Modern software programs of basin modeling allow simultaneously studying a number of processes from sedimentation and immersion to kerogen maturation and multiphase fluid flow [4-16]. Today there is a fairly large number of basin modeling software programs. The most effective for solving problems of oil and gas forecast is the program PetroMod, developed by Schlumberger. In 2016 the Faculty of Geology of Perm State National Research University received an academic license for the PetroMod basin modeling system. PetroMod software package includes advanced 1,2 and 3D technologies with technical characteristics that are currently unique in oil and gas geology and allow to determine the history of generation of hydrocarbons on the geological time scale, migration paths, number and type of oil and gas accumulations both in surface and reservoir conditions $[17,18]$.

The PetroMod 1D module serves as a tool for analyzing the results of well drilling and survey as well as calibrating 2D and 3D models. It can be used as an independent program or in combination with 2D and 3D software modules. Results of calculations are presented in the form of numerous graphs of the properties change depending on depth, geological time and history of immersion. The program allows displaying both the source and calculated data.

It is known that most of the basin modeling programs are applicable to work only with objects of relatively simple geometry and is not intended for regions of complex tectonic structure. PetroMod 1D allows to evaluate temperature and maturity even in complex thrust structures with the integration of several sections, restore the history of each geological section formation and combine them into the appropriate geochronological sequence. That also allows visualizing the complex history of the system's formation in accordance with depth, time and immersion of blocks [4-6, 17, 18].

The PetroMod 2D module is mainly used in areas with a limited amount of data, which is sufficient only for building a geological section. In practice that module can be used in structurally complex areas for rapid calculation of results and better understanding of a regional geological structure. The 2D module is also used in areas with a large amount of data for rapid analysis and 
forecast of pressures, full calculation of temperatures and pressures or a primary analysis of hydrocarbon accumulations. The results of calculations are presented in form of a series of 2D models of changing properties along the section at various intervals of geological time $[17,18]$.

The 1D-models of a number of wells, drilled into the autochthon, were calculated using the PetroMod software complex. The 2D-models of the Vuktyl thrust are built. Modeling was carried out based on an extensive database of geological, geophysical and geochemical research results [1926]. Calibration of simulation results was carried out according to actual measurements of modern temperatures and reflectivity of vitrinite (RV).

\section{Results and discussion}

The section of the Vuktyl thrust is represented by deposits of the Paleocene from the Ordovician to Permian system and Triassic one as well. It is believed that reservoirs are represented predominantly by carbonate Carboniferous-Lower Permian deposits and formations of the Famennian stage of Devonian system. The main cap rocks are clayish and argillaceous-anhydrite Upper Martian substage and Kungurian stages of the Permian system, respectively. Clays of the Tula stage have less properties of cap rocks. Fault surfaces may serve as a screen, but according to some information, tectonic faults that limit the fault can be partially permeable [27]. The models are designed taking into account the identification of at least two bodies of covers.

The module PetroMod 1D allowed to obtain the models of formation of the section and development of hydrocarbon generation processes in an area of the deepest in the region the parametric well Vuktylskaya-58 (7026 m) [28, 29]. Since the academic license of PetroMod in the module 1D does not support thrust simulation then in order to increase the objectivity of modeling thrust part of the section drilled by the parametric well Vuktylskaya-58 cover bodies were generally considered as a thick undivided Upper PermianTriassic sequence. Characterization of the section and modeling of change in the catagenesis in the allochthon were carried out separately.

Calibration of the computed models, performed using the modern measured values of temperature and $\mathrm{RV}$, showed a discrepancy with the actual data, which did not exceed 3-5\%.

The complex model of immersion, heating, and oil and gas generation of the Vuktylskaya well-58 (Fig. 2) reflects two main stages of immersion such as Ordovician-Early Permian and Middle Late Permian. Middle Late Permian is associated with development of the Ural fold belt and formation of the thrust. The dimension of the catagenetic scale considered for construction and interpretation of an oil and gas generation model is given in the Table 1.

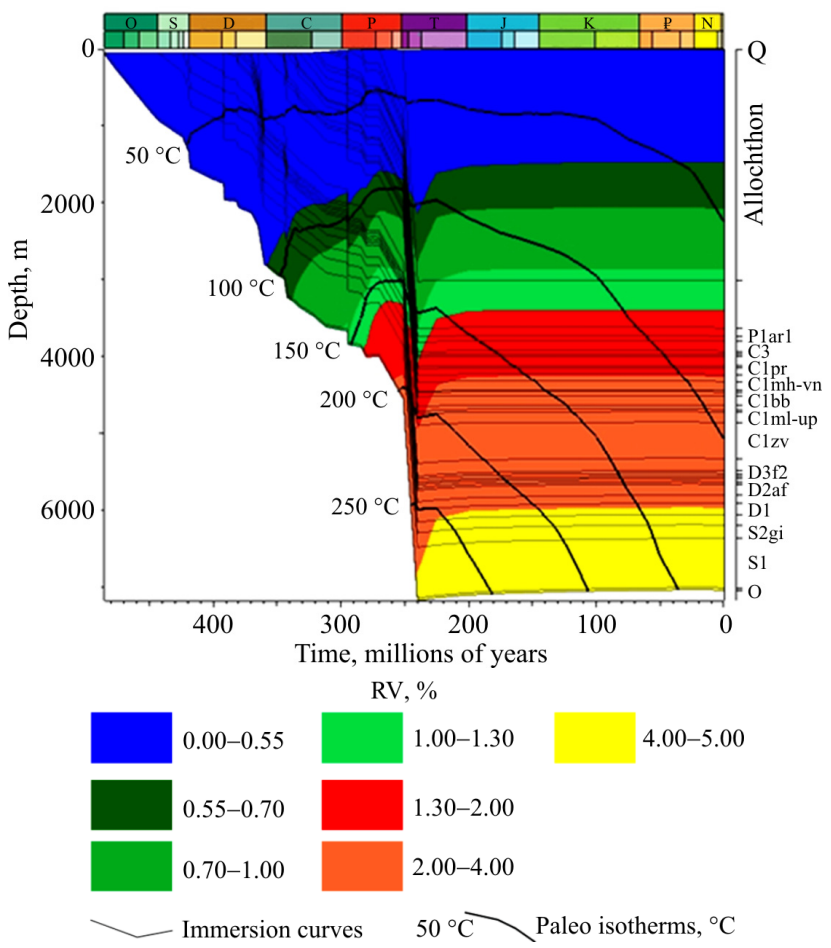

Fig. 2. Integrated model of immersion, heating and oil and gas generation according to the parametric well Vuktylskaya-58

Table 1

Considered dimension of the catagenetic scale [30] and its comparison with optical vitrinite indexes

\begin{tabular}{|c|c|c|c|c|}
\hline Substage of catagenesis & Gradation of catagenesis & $\mathrm{RV}, \%$ & \multirow{2}{*}{\multicolumn{2}{|c|}{$\begin{array}{l}\text { Degree of maturity of the organic matter of rocks } \\
\text { Stage of the immature organic matter of rocks }\end{array}$}} \\
\hline Proto-catagenesis & $\mathrm{PK}_{1}-\mathrm{PK}_{3}$ & $0.00-0.55$ & & \\
\hline \multirow[t]{4}{*}{ Meso-catagenesis } & $\mathrm{MK}_{1}$ & $0.55-0.70$ & \multirow{3}{*}{$\begin{array}{l}\text { The main zone } \\
\text { of oil generation }\end{array}$} & Initial stage of the "oil window" \\
\hline & $\mathrm{MK}_{2}$ & $0.70-1.00$ & & Peak of oil generation \\
\hline & $\mathrm{MK}_{3}$ & $1.00-1.30$ & & Final stage of the "oil window" \\
\hline & $\mathrm{MK}_{4}-\mathrm{MK}_{5}$ & $1.30-2.00$ & \multirow{2}{*}{$\begin{array}{l}\text { The main zone } \\
\text { of gas generation }\end{array}$} & Zone of wet gas \\
\hline Apo-catagenesis & $\mathrm{AK}_{1}-\mathrm{AK}_{3}$ & $2.00-4.00$ & & Zone of dry gas \\
\hline
\end{tabular}


The model of oil and gas generation is characterized by the achievement of extreme values of catagenesis (the stage of apo-catagenesis) and shows that the parent strata of the autochthon entered the main gas generation zone (MGGZ). Deposits of Ordovician and Silur reached the MGGZ during the near Ural epoch. The basement of the lower Devonian reached that during the Biarmian time. That strata came out from the MGGZ at the turn of Perm and Triassic periods. There is a relictic MGGZ found at the interval 3400-5965 $\mathrm{m}$ starting from the upper part of the lower set of the Devonian system and to the surface of the thrust shifter.

There are in the autochthonous part of the section two oil and gas parent series (OGPS) identified such as the Lower Devonian-Eifelian at the interval 5651-6046 $\mathrm{m}$ and FamennianTournaisian formation at the interval $4624-5510 \mathrm{~m}$ [29], that are characterized by a relatively low generation potential and contain dispersed organic matter. The metter is mainly composed of mixed (II and III) type of kerogen. Both OGPS entered the MOGZ during the Carboniferous period. At the same time, the parent rocks of the Tournaisian set entered the MOGZ in the Permian period during the apperiance of thrust dislocations and stayed there for a rather short period, hardly reaching all its oil potential. Lower and middle series of the Devonian system entered the MGGZ at the same time. Later on, at the beginning of the Triassic period, the Famennian deposits entered the MGGZ, and then in the middle epoch the Tournaisian ones, when traps in the section under study were already formed.

That can be seen from the integrated model of immersion, heating and oil and gas generation of allochthon (Fig. 3) that sequences from the Lower Carboniferous to the Kungurian stage of the Permian system reaches the "oil window". The upper boundary of the MOGZ is located at the depth of $1,700 \mathrm{~m}$. Deposits of the Carboniferous system at the interval 2403-3220 $\mathrm{m}$ correspond to the peak of oil generation. Deposits of the allochthonous part of the section did not enter the MGGZ.

The basis of $2 \mathrm{D}$ models was the schematic geological section of the Vuktyl thrust along the line of wells 225-58-224-221 (see Fig. 1) [3]. As a result of $2 \mathrm{D}$ modeling, the most interesting is the model of zonation of catagenesis of organic matter (changes in the present RV values) along the Vuktyl overthrust (Fig. 4), which clearly traces the zone of immature organic matter to the depth of $1450 \mathrm{~m}$ in the archpart of the allochthon anticline and up to $1,900 \mathrm{~m}$ to the east. The footplate of the MOGZ found at the depth of $3,250 \mathrm{~m}$ in the overthrust arch and is submerged up to $3,600 \mathrm{~m}$ in the eastern regions. The depth of the MOGZ in the arch is $5300 \mathrm{~m}, 5850 \mathrm{~m}$ in the east of the thrust and about $6100 \mathrm{~m}$ in the west. There is a strong apocatagenesis zone below. Increase in paleo temperatures in the arch part of the oberthrust is caused by the thermal impact of dislocations.

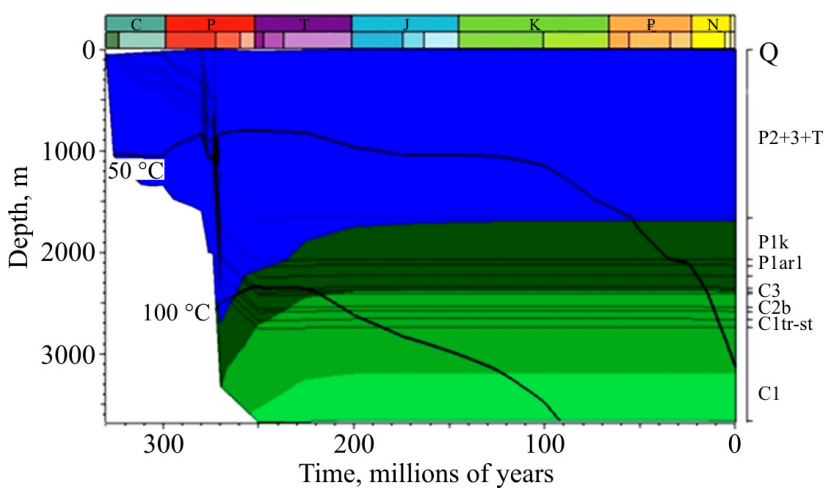

Fig. 3. Integrated model of immersion, heating and oil generation of the allochthon of the Vuktyl overthrust according to the data of parametric well Vuktylskaya-58. For notation see Fig. 2

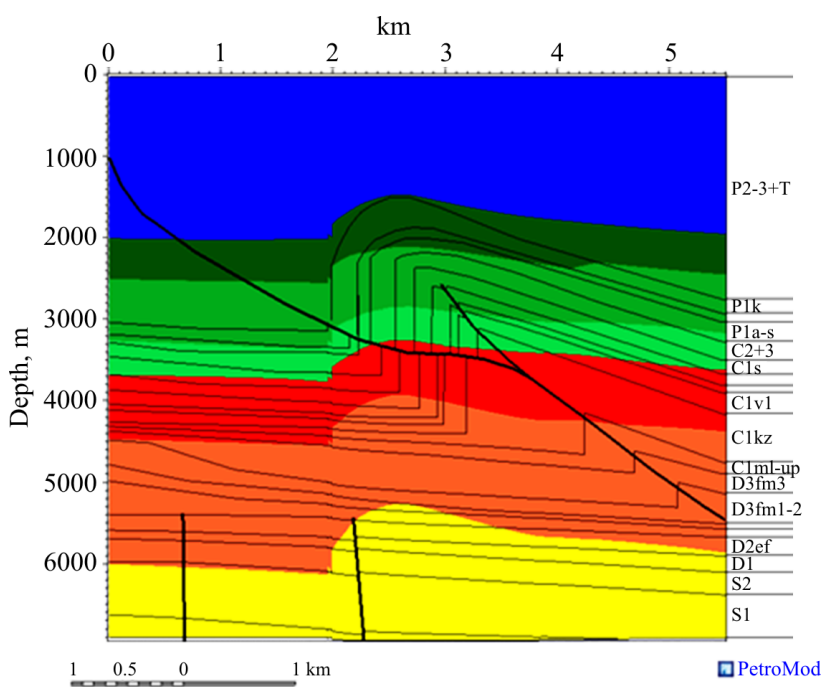

Fig. 4. Model of zonation of catagenesis along the section of the Vuktyl overthrust. For notation see Fig. 2

A brief description of location of catagenesis zones along the section of the Vuktyl overthrust is given in Table 2. 
Table 2

Depth of occurrence of catagenesis zones in the area of the Vuktyl thrust

\begin{tabular}{|c|c|c|c|}
\hline \multirow{2}{*}{$\begin{array}{c}\text { Gradation of } \\
\text { catagenesis }\end{array}$} & \multicolumn{2}{|c|}{$\begin{array}{c}\text { Depth of zone } \\
\text { occurrence, } \mathrm{m}\end{array}$} & \multirow{2}{*}{$\begin{array}{c}\text { Geological age, } \\
\text { allochthon / autochthon }\end{array}$} \\
\cline { 2 - 3 } & $\min$ & $\max$ & \\
\hline $\mathrm{PK}_{1}-\mathrm{PK}_{3}$ & 1450 & 1950 & $\mathrm{P}_{2-3}+\mathrm{T} / \mathrm{P}_{2-3}+\mathrm{T}$ \\
\hline $\mathrm{MK}_{1}$ & 2100 & 2450 & $\mathrm{P} / \mathrm{P}_{2-3}+\mathrm{T}$ \\
\hline $\mathrm{MK}_{2}$ & 2850 & 3150 & $\mathrm{C}_{1} \mathrm{tl}-\mathrm{P}_{1} \mathrm{k} / \mathrm{P}_{1} \mathrm{ar}+\mathrm{P}_{2-3}$ \\
\hline $\mathrm{MK}_{3}$ & 3250 & 3600 & $\mathrm{C}_{1} \mathrm{kz}-\mathrm{P}_{1} \mathrm{k} / \mathrm{C}_{2-3}-\mathrm{P}_{1} \mathrm{k}$ \\
\hline $\mathrm{MK}_{4}-\mathrm{MK}_{5}$ & 3900 & 4400 & $\mathrm{C}_{1} \mathrm{kz}-\mathrm{C}_{2-3} / \mathrm{C}$ \\
\hline $\mathrm{AK}_{1}-\mathrm{AK}_{3}$ & 5300 & 6100 & $\mathrm{D}_{2} \mathrm{ef}-\mathrm{C}_{1} \mathrm{kz} / \mathrm{S}_{2}-\mathrm{C}_{1} \mathrm{~S}$ \\
\hline
\end{tabular}

Appereance of the MGGZ in deep buried sediments of the autochthon of the Vuktyl overthrust is confirmed by results of testing the Vuktylskaya-58 well. As a result of testing gas productivity was revealed in the Ordovician, Middle Devonian, Tournaisian and Visean sets of the Carboniferous system (Table 3).

That can be seen on the model of transformation of organic matter of OGPS (Fig. 5), that in the Devonian and most of the Carboniferous system the transformation coefficient reaches 80-100\%. Only the upper part of Kizel, Aleksinsk-Venevsk formations in the arch part of the anticline is characterized by a lower degree of transformation that changes in the range of $40-80 \%$.

Table 3

Results of tests of deep burried deposits drilled by Vuktylskaya-58 (based on data of KamNIIKIGS JSC)

\begin{tabular}{|c|c|c|c|c|}
\hline Test interval, $\mathrm{m}$ & Test method & Geological age & Lithology & Oil and gas productivity \\
\hline $6858-7026$ & Tests in column & $\mathrm{O}$ & Dolomites & $\begin{array}{l}\text { Inflow of mud filtrate of } 0.85 \mathrm{~m}^{3} / \text { day, gas } \\
\text { rate (visually) } 0.5 \mathrm{k} \mathrm{m}^{3} / \text { day }\end{array}$ \\
\hline $6345-6410$ & While drilling & $\mathrm{S}_{1} \mathrm{~V}$ & Dolomites & Inflow not received \\
\hline $6165-6254$ & While drilling & $\mathrm{S}_{2}$ & $\begin{array}{l}\text { Intercalation of limestones with } \\
\text { dolomites and mudstones }\end{array}$ & Inflow not received \\
\hline $\begin{array}{l}5620-5652 \\
5604-5611\end{array}$ & Tests in column & $\mathrm{D}_{2} \mathrm{~g}$ & Sandstones & Inflow of gas with rate of $11 \mathrm{k} \mathrm{m}^{3} /$ day \\
\hline $5604-5652$ & Tests in column & $\mathrm{D}_{2} \mathrm{ef}$ & Sandstones & $\begin{array}{l}\text { Condensate (gas?) with signs of formation } \\
\text { water with calculated rate of } 11 \mathrm{k} \mathrm{m}^{3} / \text { day }\end{array}$ \\
\hline $\begin{array}{l}4775-4810 \\
4780-4788\end{array}$ & Tests in column & $\mathrm{C}_{1} \mathrm{t}$ & $\begin{array}{l}\text { Limestones with interlayers of } \\
\text { dolomites }\end{array}$ & $\begin{array}{l}\text { Inflow of gas condensate with gas } \\
\text { production rate } 12 \mathrm{~km}^{3} / \text { day with } \\
5 \% \text { mix of formation water }\end{array}$ \\
\hline $4775-4810$ & Tests in column & $\mathrm{C}_{1} \mathrm{t}$ & $\begin{array}{l}\text { Limestones with interlayers of } \\
\text { dolomites }\end{array}$ & Inflow of oil rate of $8 \mathrm{~m}^{3} /$ day \\
\hline $4784.5-4819$ & While drilling & $\mathrm{C}_{1} \mathrm{t}$ & $\begin{array}{l}\text { Limestones with interlayers of } \\
\text { dolomites }\end{array}$ & $\begin{array}{l}\text { The inflow of gas condensate with gas } \\
\text { recalculation rate of } 12 \mathrm{~km}^{3} / \text { day }\end{array}$ \\
\hline $\begin{array}{l}4573-4584 \\
4519-4548\end{array}$ & While drilling & $\mathrm{C}_{1} \mathrm{v}$ & $\begin{array}{l}\text { Intercalation of siltstones, } \\
\text { sandstones and mudstones }\end{array}$ & $\begin{array}{l}\text { The inflow of gas condensate mix with rate } \\
\text { of } 0.5 \mathrm{~km}^{3} / \text { day }\end{array}$ \\
\hline
\end{tabular}

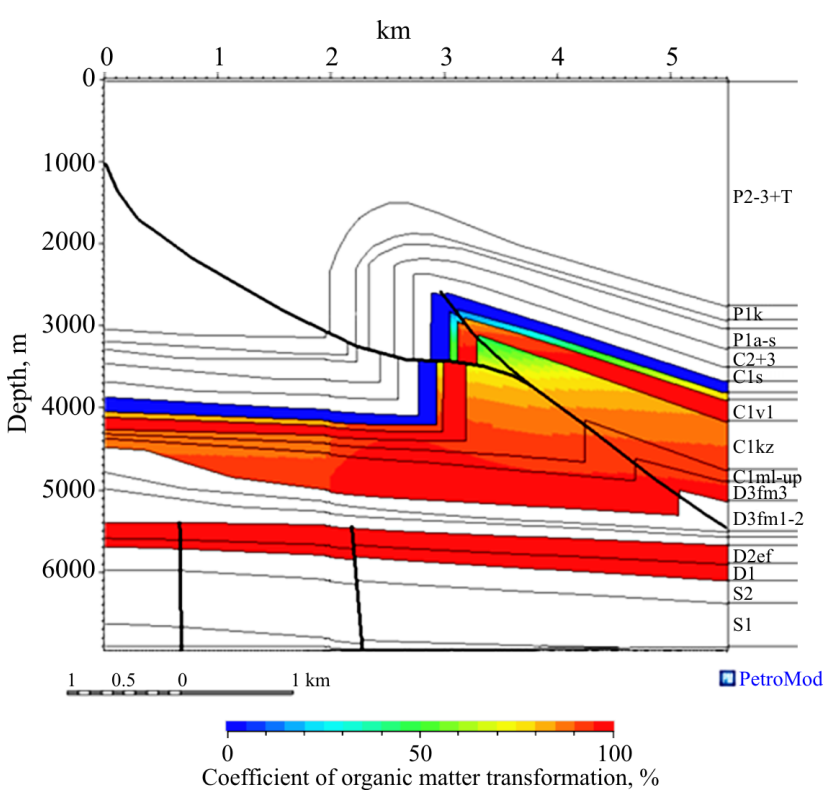

Fig. 5. Model of change of coefficient of transformation of OGPS organic matter along the Vuktyl overthrust

\section{Conclusion}

Based on the results of 1 and 2D basin modeling of the development area of the Vuktylskiy overthrust by the PetroMod program software it can be concluded that: 1) parent rocks of the allochthonous section, where the main gas condensate deposit of the Vuktylskiy field is located, could mainly generate oil only; 2) allochthon deposits did not enter the "oil window" until the thrust dislocations occured, except for a basement of the Carboniferous system, which reached the MOGZ in the early Permian period; 3) there are mainly the processes of generation of gases and gas condensates took place in the autochthon that could ensure the generation of deposits at high depths and in the allochthon of the Vuktylskoe field. The occurence of gas generation processes in deep buried deposits significantly increases 
their gas content. This is also proved by the discovery of a big number of gas occurance of a significant scale below 4-5 km. Generation and accumulation of gas hydrocarbons occurred in time favorable for generation of deposits, mainly after the appearance of thrust dislocations when the main traps were formed in deep burried strata.

\section{References}

1. Pankratova E.I., Iunusova L.V., Bogdanov B.P. Kompleksnyi analiz geologo-geofizicheskikh dannykh i parametrov razrabotki dlia obosnovaniia sistemy plastovykh zalezhei $\mathrm{v}$ allokhtone $\mathrm{i}$ avtokhtone Vuktyl'skogo neftegazokondensatnogo mestorozhdeniia [Comprehensive analysis of geological-geophysical data and development parameters to justify system of bedded deposits in allochthon and autochthon of vuktyl oil and gas condensate field]. Georesursy, 2016, vol.18, no.2, pp.8793. DOI: $10.18599 / \mathrm{grs} / 18.2 .2$

2. Danilov V.N. Perspektivy vospolneniia syr'evoi bazy Vuktyl'skogo neftegazokondensatnogo mestorozhdeniia [Outlooks for supplementation of raw materials reserves at the Vuktyl oil-gas- condensate field]. Vesti gazovoi nauki, 2016, no.1 (25), pp.75-82.

3. Kuznetsova E.A., Oborin A.A. Perspektivy neftegazonosnosti avtokhtona Vuktyl'skogo nadviga [Prospects of oil and gas content of the autochthon of the Vuktyl overthrust]. Geologiia v razvivaiushchemsia mire, Perm', 2011, pp.187-189.

4. Kuznetsova E.A. Perspektivy neftegazonosnosti iuzhnoi chasti Verkhnepechorskoi depressii po dannym 1D basseinovogo modelirovaniia [Prospects of oil and gas potential in the southern part of the Upper Pechora depression according to 1D basin modeling]. Vestnik Permskogo universiteta. Geologiia, 2017, vol.16, no.2, pp.179-184. DOI: 10.17072/psu.geol.16.2.179

5. Kuznetsova E.A. Rezul'taty 1D basseinovogo modelirovaniia Timano-Pechorskoi glubokoi opornoi skvazhiny programmnym kompleksom PetroMod [Results of 1D basin modeling of the Timano-Pechora deep well with the PetroMod software package]. Geologiia $i$ poleznye iskopaemye Zapadnogo Urala, Perm', 2017, pp.96-100.

6. Kerimov V.Iu., Khantshel T., Sokolov K., Sidorova M.S. Primenenie tekhnologii basseinovogo modelirovaniia programmnogo paketa PetroMod v uchebnom protsesse RGU nefti i gaza im. I.M. Gubkina [Application of the technology of basin modeling - the software package PetroMod in the educational process of the RGU of oil and gas named after I.M. Gubkin]. Neft', gaz i biznes, 2011, no.4, pp.38-47.

7. Allen A.Ph., Allen J.R. Basin analysis: principles and application to petroleum play assessment. 3 ed. WileyBlackwell, 2013, 619 p.

8. Al-Hajeri M.M., Al Saeed M., Derks J. et al. Basin and petroleum system modeling. Oilfield Rewiew, 2009, vol.21, iss.2, pp.14-29.

9. Roeder D., Goffey G.P., Craig J. et al. Fold-thrust belts at peak oil. Hydrocarbons in contact belts. London, Geological Society, 2010, vol.348, pp.7-31. DOI: 10.1144/SP348.2 0305-8719/10/\$15.00

10. Hantschel T., Kauerauf A. Fundamentals of basin and petroleum systems modeling. Berlin, Springer-Verlag, 2009, 476 p. DOI: 10.1007/978-3-540-72318-9

11. Roure F., Swennen R., Schneider F. et al. Incidence and importance of tectonics and natural fluid migration on reservoir evolution in foreland fold-andthrust belts. Oil and Gas Science and Technology Revue de l'IFP, 2005, vol.60, no.1, pp.67-106. DOI: 10.2516/ogst: 2005006.
12. Neumaier M., Littke R., Hantschel T. et al. Integrated charge and seal assessment in the Monagas fold and thrust belt of Venezuela. AAPG Bulletin, 2014, vol.98, no.7, pp.1325-1350. DOI: 10.1306/01131412157

13. Maerten L., Maerten F. Chronologic modeling of faulted and fractured reservoirs using geomechanically based restoration. Technique and industry applications: AAPG Bulletin, vol.90, no.8, pp.1201-1226. DOI: 10.1306/02240605116.

14. Magoon L.B., Dow W.G. The Petroleum system: from source to trap. Tulsa, Oklahoma, AAPG, 1994, 655 p. DOI: $10.1306 / \mathrm{M} 60585$

15. Nemcok M., Schamel S., Gayer R. Thrustbelts. Structural architecture. Thermal Regimes and Petroleum Systems, 2009, 527 p. DOI: 10.2113/gscanmin.44.6.1563

16. Schneider F. Basin modeling in complex area: examples from Eastern Venezuelan and Canadian Foothills. Oil and Gas Science and Technology, 2003, vol.58, no.2, pp.313-324. DOI: 10.2516/ogst:2003019

17. PetroMod petroleum system modeling. Schlumberger Information Solutions, 2011, no.10, 256 p.

18. PetroMod, available at: http://sis.slb.ru/upload/ iblock/355/petromod1d2d.pdf (accessed: 13 February 2017).

19. Belokon' A.V. Modelirovanie tektonicheskoi i temperaturnoi istorii raiona bureniia Timano-Pechorskoi glubokoi opornoi skvazhiny [Modeling of tectonic and temperature history of the Timan-Pechorskaya deep well drilling area]. Vestnik Permskogo gosudarstvennogo tekhnicheskogo universiteta, 2000, no.3, pp.71-76.

20. Galkin V.I., Kozlova I.A. Vliianie istorikogeneticheskikh faktorov na neftegazonosnost' [Influence of historical genetic factors on oil and gas potential]. Vestnik Permskogo universiteta. Geologiia, 2000, iss.4, pp.8-18.

21. Galushkin Iu.I. Modelirovanie osadochnykh basseinov i otsenka ikh neftegazonosnosti [Modelling of sedimentary basins and assessment of their oil and gas potential]. Moscow, Nauchnyi mir, 2007, 456 p.

22. Krivoshchekov S.N. Otsenka perspektivnosti Rusinovskoi podgotovlennoi struktury (iugo-vostok Verkhnepechorskoi depressii) [Estimation of the prospects of the Rusinovskaya prepared structure (southeast of the Upper Pechora depression)]. Vestnik Permskogo natsional'nogo issledovatel'skogo politekhnicheskogo universiteta. Geologiia. Neftegazovoe i gornoe delo, 2007, no.2, pp.22-25.

23. Krivoshchekov S.N., Kozlova I.A. Verkhnepechorskaia depressiia - novyi ob"ekt poiskovo-razvedochnykh rabot na neft' i gaz v Permskom krae [The Upper Pechora Depression is a new object of prospecting for oil and gas in the Perm region]. Vestnik Permskogo natsional'nogo issledovatel'skogo politekhnicheskogo universiteta. Geologiia. Neftegazovoe i gornoe delo, 2006, no.1, pp.51-58.

24. Pestereva S.A. Metodicheskie osnovy i problemy basseinovogo modelirovaniia 1D [Methodical basics and problems of basin modeling 1D]. Geologiia i neftegazonosnost' severnykh raionov Uralo-Povolzh'ia: sbornik nauchnykh trudov $k$ 100-letiiu so dnia rozhdeniia professora P.A. Sofronitskogo. Perm', Izdatel'stvo Permskogo gosudarstvennogo universiteta, 2010, pp.231-232.

25. Pestereva S.A., Popov S.G., Belokon' A.V. Istoriko-geneticheskoe modelirovanie evoliutsii 
osadochnogo chekhla $\mathrm{V}$ raionakh razvitiia glubokopogruzhennykh otlozhenii Timano-Pechorskogo neftegazonosnogo basseina [Historical and genetic modeling of the evolution of the sedimentary cover in the areas of development of deep-seated deposits of the Timan-Pechora oil and gas basin]. Vestnik Permskogo universiteta. Geologiia, 2011, iss.2, pp.8-19.

26. Shilov G.Ia., Vasilenko E.I. Opyt primeneniia termobaricheskikh parametrov razreza dlia otsenki perspektiv neftegazonosnosti dlia otsenki neftenosnosti ploshchadei Predural'skogo progiba [Experience in applying the thermobaric parameters of the section for assessing the prospects of oil and gas potential for estimating the oil content of the areas of the Predural trough]. Karotazhnik, 2013, no.233, pp.37-46.

27. Pankratova E.I., Bogdanov B.P. Geologicheskie predposylki vyiavleniia plastovykh zalezhei $\mathrm{V}$ otlozheniiakh permi-karbona avtokhtona Vuktyl'skogo neftegazokondensatnogo mestorozhdeniia [Geological prerequisites for identifying reservoir deposits in Permian-Carboniferous autochton sediments of the Vuktyl oil and gas condensate field]. Neftegazovaia geologiia. Teoriia $i$ praktika, 2015, vol.10, no.3, available at: http://www.ngtp.ru/rub/4/ 30_2015.pdf. DOI: $\quad 10.17353 / 2070-5379 / 302015$ (accessed: 13 February 2017).

28. Beliaeva G.L., Karaseva T.V., Kuznetsova E.A. Geologicheskoe stroenie i neftegazonosnost' glubokopogruzhennykh otlozhenii Timano-Pechorskoi NGP [Geological structure and oil and gas content of the deep burried sediments of the Timan-Pechora OGP]. Geologiia, geofizika i razrabotka neftianykh $i$ gazovykh mestorozhdenii, 2012, no.7, pp.33-40.

29. Kochneva O.E., Karaseva T.V., Kuznetsova E.A. Perspektivy neftegazonosnosti glubokopogruzhennykh otlozhenii Verkhnepechorskoi vpadiny po dannym basseinovogo modelirovaniia [Prospects of oil and gas content of deep buried sediments of the Upper Pechora Basin according to basin modeling data]. Neftianoe khoziaistvo, 2015, no.3, pp.14-16.

30. Vassoevich N.B., Korchagina Iu.I., Lopatin N.V. et al. Glavnaia faza nefteobrazovaniia [The main phase of oil formation]. Vestnik Moskovskogo gosudarstvennogo universiteta. Seriia: Geologiia, 1969, no.6, pp.3-27.

\section{Библиографический список}

1. Панкратова Е.И., Юнусова Л.В., Богданов Б.П. Комплексный анализ геолого-геофизических данных и параметров разработки для обоснования системы пластовых залежей в аллохтоне и автохтоне Вуктыльского нефтегазоконденсатного месторождения // Георесурсы. 2016. - T. 18, № 2. - C. 87-93. DOI:10.18599/grs/18.2.2

2. Данилов В.Н. Перспективы восполнения сырьевой базы Вуктыльского нефтегазоконденсатного месторождения // Вести газовой науки. - 2016. № 1 (25). - С. 75-82.

3. Кузнецова Е.А., Оборин А.А. Перспективы нефтегазоносности автохтона Вуктыльского надвига // Геология в развивающемся мире. - Пермь, 2011. C. $187-189$.

4. Кузнецова Е.А. Перспективы нефтегазоносности южной части Верхнепечорской депрессии по данным $1 \mathrm{D}$ бассейнового моделирования // Вестник Пермского университета. Геология. - 2017. - Т. 16, № 2 - С. 179184. DOI: 10.17072/psu.geol.16.2.179.

5. Кузнецова Е.А. Результаты 1D бассейнового моделирования Тимано-Печорской глубокой опорной скважины программным комплексом PetroMod // Геология и полезные ископаемые Западного Урала. Пермь, 2017. - С. 96-100.

6. Применение технологии бассейнового моделирования - программного пакета PetroMod в учебном процессе РГУ нефти и газа им. И.М. Губкина / В.Ю. Керимов, Т. Хантшел, К. Соколов, М.С. Сидорова // Нефть, газ и бизнес. - 2011. - № 4. - С. 38-47.

7. Allen A.Ph., Allen J.R. Basin analysis: principles and application to petroleum play assessment. -3 ed. Wiley-Blackwell, 2013. - 619 p.

8. Basin and petroleum system modeling / M.M. AlHajeri, M. Al Saeed, J. Derks [et al.] // Oilfield Rewiew. 2009. - Vol. 21, iss. 2. - P. 14-29.

9. Fold-thrust belts at peak oil / D. Roeder, G.P. Goffey, J. Craig [et al.] // Hydrocarbons in contact belts. - London: Geological Society, 2010. - Vol. 348. P. 7-31. DOI: 10.1144/SP348.2 0305-8719/10/\$15.00

10. Hantschel T., Kauerauf A. Fundamentals of basin and petroleum systems modeling. - Berlin: SpringerVerlag, 2009. - 476 p. DOI: 10.1007/978-3-540-72318-9

11. Incidence and importance of tectonics and natural fluid migration on reservoir evolution in foreland foldand-thrust belts / F. Roure, R. Swennen, F. Schneider [et al.] // Oil and Gas Science and Technology Revue de l'IFP. - 2005. - Vol. 60, №. 1. - P. 67-106. DOI: 10.2516/ogst: 2005006.

12. Integrated charge and seal assessment in the Monagas fold and thrust belt of Venezuela / M. Neumaier, R. Littke, T. Hantschel [et al.] // AAPG Bulletin. 2014. - Vol. 98, №. 7. - P. 1325-1350. DOI: $10.1306 / 01131412157$

13. Maerten L., Maerten F. Chronologic modeling of faulted and fractured reservoirs using geomechanically based restoration // Technique and industry applications: AAPG Bulletin. - 2006. - Vol. 90, № 8. - P. 1201-1226. DOI: $10.1306 / 02240605116$.

14. Magoon L.B., Dow W.G. The Petroleum system: from source to trap. - Tulsa, Oklahoma: AAPG, 1994. 655 p. DOI: $10.1306 / \mathrm{M} 60585$

15. Nemcok M., Schamel S., Gayer R. Thrustbelts. Structural architecture // Thermal Regimes and Petroleum Systems. - 2009. - 527 p. DOI: 10.2113/gscanmin.44.6.1563

16. Schneider F. Basin modeling in complex area: examples from Eastern Venezuelan and Canadian Foothills // Oil and Gas Science and Technology. 2003. - Vol. 58, № 2. - P. 313-324. DOI: $10.2516 /$ ogst:2003019

17. PetroMod petroleum system modeling // Schlumberger Information Solutions. - 2011. - № 10. - $256 \mathrm{p}$.

18. PetroMod [Электронный pecypc]. - URL: http://sis.slb.ru/upload/iblock/355/petromod1d2d.pdf (дата обращения: 13.02.2017). 
19. Белоконь А.В. Моделирование тектонической и температурной истории района бурения ТиманоПечорской глубокой опорной скважины // Вестник Пермского государственного технического университета. - 2000. - № 3. - С. 71-76.

20. Галкин В.И., Козлова И.А. Влияние историкогенетических факторов на нефтегазоносность // Вестник Пермского университета. Геология. - 2000. Вып. 4. - С. 8-18.

21. Галушкин Ю.И. Моделирование осадочных бассейнов и оценка их нефтегазоносности. - М.: Научный мир, 2007. - 456 с.

22. Кривощеков С.Н. Оценка перспективности Русиновской подготовленной структуры (юго-восток Верхнепечорской депрессии) // Вестник Пермского национального исследовательского политехнического университета. Геология. Нефтегазовое и горное дело. 2007. - № 2. - С. 22-25.

23. Кривощеков С.Н., Козлова И.А. Верхнепечорская депрессия - новый объект поисково-разведочных работ на нефть и газ в Пермском крае // Вестник Пермского национального исследовательского политехнического университета. Геология. Нефтегазовое и горное дело. 2006. - № 1. - С. 51-58.

24. Пестерева С.А. Методические основы и проблемы бассейнового моделирования 1D // Геология и нефтегазоносность северных районов Урало-Поволжья: сб. науч. тр. к 100-летию со дня рождения проф. П.А. Софроницкого. Пермь: Изд-во Перм. гос. ун-та, 2010. - С. 231-232.

25. Пестерева С.А., Попов С.Г., Белоконь А.В. Историко-генетическое моделирование эволюции осадочного чехла в районах развития глубокопогруженных отложений Тимано-Печорского нефтегазоносного бассейна // Вестник Пермского университета. Геология. - 2011. - Вып. 2. - С. 8-19.

26. Шилов Г.Я., Василенко Е.И. Опыт применения термобарических параметров разреза для оценки перспектив нефтегазоносности для оценки нефтеносности площадей Предуральского прогиба // Каротажник. - 2013. - № 233. - С. 37-46.

27. Панкратова Е.И., Богданов Б.П. Геологические предпосылки выявления пластовых залежей в отложениях перми-карбона автохтона Вуктыльского нефтегазоконденсатного месторождения [Электронный pecypc] // Нефтегазовая геология. Теория и практика. 2015. - T. 10. - № 3. - URL: http://www.ngtp.ru/rub/ 4/30_2015.pdf/, DOI: 10.17353/2070-5379/30_2015 (дата обращения: 13.02.2017).

28. Беляева Г.Л., Карасева Т.В., Кузнецова Е.А. Геологическое строение и нефтегазоносность глубокопогруженных отложений Тимано-Печорской НГП // Геология, геофизика и разработка нефтяных и газовых месторождений. - 2012. - № 7. - С. 33-40.

29. Кочнева О.Е., Карасева Т.В., Кузнецова Е.А. Перспективы нефтегазоносности глубокопогруженных отложений Верхнепечорской впадины по данным бассейнового моделирования // Нефтяное хозяйство. 2015. - № 3. - C. 14-16.

30. Главная фаза нефтеобразования / Н.Б. Вассоевич, Ю.И. Корчагина, Н.В. Лопатин [и др.] // Вестник Московского государственного университета. Сер. Геология. - 1969. - № 6. - С. 3-27.

Please cite this article in English as:

Kuznetsova E.A., Karaseva T.V. Features of geological structure and formation of oil \& gas deposits in the Vuktyl thrust fault region. Perm Journal of Petroleum and Mining Engineering, 2017, vol.16, no.4, pp.313-320. DOI: 10.15593/2224-9923/2017.4.2

Просьба ссылаться на эту статью в русскоязычных источниках следующим образом:

Кузнецова Е.А., Карасева Т.В. Особенности геологического строения и формирования нефтегазоносности в районе вуктыльского надвига // Вестник Пермского национального исследовательского политехнического университета. Геология. Нефтегазовое и горное дело. - 2017. - Т.16, №4. - C.313-320. DOI: 10.15593/2224-9923/2017.4.2 